\title{
Seasonal influence on the hematological parameters in cultured Nile tilapia from southern Brazil
}

\author{
Jerônimo, GT., Laffitte, LV., Speck, GM. and Martins, ML.* \\ Laboratório AQUOS - Sanidade de Organismos Aquáticos, Centro de Ciências Agrárias - CCA, \\ Universidade Federal de Santa Catarina - UFSC, Rod. Admar Gonzaga, 1346, CEP 88040-900, Florianópolis, SC, Brazil \\ *e-mail: mlaterca@cca.ufsc.br
}

Received June 14, 2010 - Accepted September 17, 2010 - Distributed August 31, 2011

\begin{abstract}
This study evaluated seasonality in hematological parameters of Nile tilapia cultured in the state of Santa Catarina, southern Brazil. A total of 240 fish were examined during four seasons between April 2007 and March 2008 in three different fish farms. After being anesthetised in a benzocaine solution, blood samples were withdrawn into syringes containing a drop of $10 \%$ EDTA for hematological analysis. The results were compared between fish farms and seasons, which are well delimited in southern Brazil. In a traditional fish farm in Joinville in the summer, there was an increase in the percentage of hematocrit and in the red blood cell count. The highest values of total leukocytes were found in fish from fee-fishing in Blumenau in the autumn while the lowest values occurred in those from swine consorted system in Ituporanga in the summer. Thrombocytosis was observed in the autumn, and lymphocytosis was found in both the autumn and winter in tilapia from all fish farms investigated. Neutrophilia was only observed in winter and autumn in fish from Blumenau and Ituporanga. This work demonstrated the influence of seasonality and the handling characteristics of each fish farm on certain hematological parameters in Nile tilapia.
\end{abstract}

Keywords: Oreochromis niloticus, fish farm, hematology, seasonality, Brazil.

\section{Influência da sazonalidade sobre os parâmetros hematológicos de tilápia-do-nilo cultivada no Sul do Brasil}

\begin{abstract}
Resumo
Neste presente estudo avaliou-se a influência da sazonalidade sobre os parâmetros hematológicos de tilápia-do-nilo cultivada no estado de Santa Catarina, Sul do Brasil. Um total de 240 peixes foi examinado durante as quatro estações do ano, entre abril de 2007 e março de 2008 em pisciculturas de três diferentes sistemas de cultivo. Após anestesia com benzocaína, amostras de sangue foram coletadas com seringas contendo EDTA 10\% para análise hematológica. Os resultados foram comparados entre as pisciculturas e as estações, as quais são bem definidas no Sul do Brasil. Nos peixes de piscicultura tradicional em Joinville, no verão, houve aumento no hematócrito e do número de eritrócitos. Os maiores valores de leucócitos totais foram observados no outono nos animais de pesque-pague em Blumenau, enquanto os menores valores nos animais oriundos de piscicultura consorciada com suínos em Ituporanga no verão. Trombocitose foi observada no outono, e linfocitose ocorreu tanto no outono quanto no inverno em tilápia de todas as propriedades analisadas. Neutrofilia apenas foi observada no inverno e outono nos peixes de Blumenau e Ituporanga. Este estudo demonstrou a influência da sazonalidade e das características de manejo de cada piscicultura sobre os parâmetros hematológicos de tilápia-do-nilo.
\end{abstract}

Palavras-chave: Oreochromis niloticus, piscicultura, hematologia, sazonalidade, Brasil. 


\section{Introduction}

Hematological parameters are among the most important indicators of fish health (De Pedro et al., 2005; Martins et al., 2008), and changes in the proportion of blood cells may be indicative of a disease or an exposure to chemicals (De Pedro et al., 2005). Hematology must be analysed when animals are exposed to environmental changes due to pollutants (Ranzani-Paiva and Godinho, 1985), stress (Martins et al., 2004a), infections (Benli and Yavuzcan, 2004; Martins et al., 2008), parasitism (Martins et al., 2004b) and seasonality (De Pedro et al., 2005).

The Nile tilapia, Oreochromis niloticus Linnaeus 1766, a cichlid fish, is a species of economic importance for the south of Brazil. This species supports the most profitable business for fish farmers and presents an alternative to fee fishing, production or swine-consorted systems (SouzaFilho et al., 2003).

In Brazil, hematological variables in tilapia have been studied in several different situations (Tavares-Dias et al., 2000; Tavares-Dias and Moraes, 2003, Martins et al., 2004a). In southern Brazil, Azevedo et al. (2006a,b) and Ghiraldelli et al. (2006a) reported on hematological parameters of Nile tilapia from different production systems. However, the influence of seasonality on hematological parameters in farm-raised fish has not been documented to date.

Although hematology has been examined in several studies, few studies have related seasonality to blood cell parameters. In Brazil, Ranzani-Paiva et al. (2005) showed changes in the hematological parameters in tilapia from the Guarapiranga reservoir, southeast Brazil examined from August 1996 to April 1998. Hofer et al. (2000) found erythropoiesis and a high abundance of lymphocytes. On the other hand, hematological parameters in the tench (Tinca tinca Linnaeus, 1758) were found to be related to seasonality by De Pedro et al. (2005).
The aim of this study was to analyse the hematological parameters of Nile tilapia raised in three different production systems during the well-characterised seasons (spring, summer, autumn, winter) of southern Brazil.

\section{Materials and Methods}

A total of 240 reverted tilapia were collected between April 2007 and March 2008, with 20 specimens collected in each season from three different production systems located in the cities of Joinville ( $26^{\circ} 24^{\prime} 52^{\prime \prime} \mathrm{S}, 48^{\circ} 50^{\prime} 44^{\prime \prime} \mathrm{W}$ ), Blumenau (26 $\left.55^{\circ} 10^{\prime \prime} \mathrm{S}, 49^{\circ} 03^{\prime} 58^{\prime} \mathrm{W}\right)$ and Ituporanga (27 $24^{\prime} 52^{\prime \prime}$ 'S , 49 $36^{\prime} 09^{\prime \prime}$ '), in the state of Santa Catarina, southern Brazil. The mean lengths and weights of the fish were $21.2 \pm 3.7 \mathrm{~cm}$ and $236.9 \pm 128.9 \mathrm{~g}$ in fish from Joinville; $26.3 \pm 4.0 \mathrm{~cm}$ and $348.9 \pm 151.0 \mathrm{~g}$ in fish from Blumenau; and $26.0 \pm 2.8 \mathrm{~cm}$ and $486.4 \pm 198.5 \mathrm{~g}$ in fish from Ituporanga, respectively.

During sampling days the aquatic parameters such as $\mathrm{pH}$, temperature, dissolved oxygen and transparency were measured on each sampling day at 9 AM A $500 \mathrm{~mL}$ water sample was frozen for ammonia analysis at each site on each sampling day (Grasshoff, 1976) (Table 1). Fish were anesthetised in a benzocaine solution $\left(50 \mathrm{mg} . \mathrm{L}^{-1}\right)$ and a $2 \mathrm{~mL}$ blood sample was taken from the caudal vein using a syringe containing a drop of $10 \%$ EDTA solution (Ethic Committee $n^{\circ}$ 23080055748/2006-04/CEUA/UFSC). The blood was used to measure hematocrit percentage (Goldenfarb et al., 1971), the number of red blood cells (RBC) was determined using a hemocytometer Neubauer chamber, while the numbers of white blood cells (WBC) and thrombocytes were obtained using an indirect method (Ishikawa et al., 2008). The differential count of leucocytes was done using a combination of Giemsa/May-Grunwald (Rosenfeld, 1947) staining in which a hundred cells were counted to determine the cell percentage.

Table 1. Handling characteristics of fish farm in each region of the state of Santa Catarina, southern Brazil.

\begin{tabular}{lccc}
\hline \multirow{2}{*}{ Characteristics } & Localities & \\
\cline { 2 - 4 } & $\begin{array}{c}\text { Traditional fish } \\
\text { farm Joinville }\end{array}$ & $\begin{array}{c}\text { Fee-fishing } \\
\text { Blumenau }\end{array}$ & $\begin{array}{c}\text { Consorted with pig } \\
\text { manure Ituporanga }\end{array}$ \\
\hline Culture system & $\begin{array}{c}\text { Production of fingerlings } \\
\text { and juveniles }\end{array}$ & Fee fishing & Swine consorted \\
Area (ha) & 2.35 & 0.8 & 8 \\
Stocks (fish $\left./ \mathrm{m}^{2}\right)$ & 0.75 & 2 & 3.5 to 4 \\
Feeding & 1 time a day & 1 time a day & 2 times a day at the \\
Type of diet & Comercial diet & Comercial diet & Comercial diet \\
Aeration & $28 \%$ crude protein & $32 \%$ crude protein & $32 \%$ crude protein \\
Fish entrance & In emergency cases & 3 times a day & No \\
Water renewal & No & Yes & No \\
Water quality monitoring & $10 \%$ a day & - & No renewal \\
\hline
\end{tabular}


The means of the analysis were compared using variance analysis and a $t$-test at a $5 \%$ probability level (Zar, 1999). The results were compared among seasons in each facility and among facilities within each season. The water analysis was not compared statistically because the measurements were taken only on the sampling day. Hence, these data are just descriptive.

\section{Results}

Table 1 summarises the handling conditions used in each facility. There was no variation in $\mathrm{pH}$ throughout the study period. The lowest oxygen levels were observed in Ituporanga during summer and winter and the highest water temperatures in Blumenau were registered in spring and summer (Table 2). Ammonia levels, as well as water transparency, were similar both in fee-fishing and in the consorted fish with pig manure. This fact can be attributed to the conditions of each farm, which present higher or lower input of organic matters. On the other hand, in the traditional fish farm with continuous flow of water, ammonia levels were lower and the water transparency higher than that observed in the other facilities.

In autumn, fish from Blumenau showed the highest $(\mathrm{p}<0.05)$ numbers of RBC (Table 3$)$. In winter, fish from Ituporanga had high $\mathrm{RBC}, \mathrm{WBC}$ and thrombocyte counts. On the other hand, lower RBC, WBC and thrombocyte counts were found in spring in fish from the Joinville facility. In summer, hematological parameters did not vary significantly $(\mathrm{p}>0.05)$ among the facilities (Table 3 ).

With regards to the hematocrit, fish from Joinville showed high values $(\mathrm{p}<0.05)$ in summer, while fish from Ituporanga showed lower values during winter and spring. Significant increases $(\mathrm{p}<0.05)$ in the $\mathrm{RBC}$ and total thrombocyte count were observed in fish from Joinville during autumn. Fish captured in Blumenau showed an increase in RBC and WBC numbers in autumn. However, the total thrombocyte count was significantly reduced $(p<0.05)$ in summer. In the municipality of Ituporanga, an increase in hematocrit was found during autumn and summer, while the RBCs and WBCs increased in winter. Reduced total thrombocyte counts in fish from Ituporanga were related (Table 3).

There was an increase $(p<0.05)$ in the number of monocytes in fish from Blumenau in autumn and winter compared to that observed in the other facilities (Table 4). The highest numbers of monocytes were observed in fish from Joinville in winter and Blumenau in autumn and winter. Nevertheless, an increase in the lymphocyte number in fish from Ituporanga in winter and spring was observed. Apart from the other seasons, these cell counts were higher in fish from Ituporanga. Fish examined in Blumenau showed an increase in lymphocyte counts in winter, spring and summer. A large number of circulating neutrophils $(\mathrm{p}<0.05)$ was also related in fish from Joinville in spring and in those from Ituporanga in the autumn. Basophil levels in the circulating blood were low and there were no differences between the different seasons and facilities $(\mathrm{p}>0.05)$.

\section{Discussion}

Water quality was within the tolerated limits for tilapia in terms of oxygen levels and variations in $\mathrm{pH}$ (Zaniboni-Filho, 2004). The other variables, measured from the three study facilities, were maintained adequate

Table 2. Water quality of ponds measured on the sampling day in each season in the state of Santa Catarina, southern Brazil.

\begin{tabular}{|c|c|c|c|c|}
\hline \multirow{2}{*}{ Parameters } & Autumn & Winter & Spring & Summer \\
\hline & \multicolumn{4}{|c|}{ Traditional fish farm Joinville } \\
\hline Dissolved oxygen $\left(\mathrm{mg} . \mathrm{L}^{-1}\right)$ & 8.94 & 6.2 & 5.33 & 5.86 \\
\hline Transparency & 38 & 77 & 31 & 48 \\
\hline $\mathrm{pH}$ & 7.7 & 7.5 & 6.5 & 6 \\
\hline Ammonia (mg. $\left.\mathrm{L}^{-1}\right)$ & 0.5 & 0.3 & 0.5 & 0.15 \\
\hline \multirow[t]{2}{*}{ Temperature $\left({ }^{\circ} \mathrm{C}\right)$} & 20.3 & 18.1 & 22.5 & 22.9 \\
\hline & \multicolumn{4}{|c|}{ Fee-fishing Blumenau } \\
\hline Dissolved oxygen $\left(\mathrm{mg} . \mathrm{L}^{-1}\right)$ & 5.77 & 4.1 & 4.46 & 4.44 \\
\hline Transparency & 11 & 15 & 15 & 8 \\
\hline $\mathrm{pH}$ & 7.02 & 7.2 & 7.4 & 7.32 \\
\hline Ammonia $\left(\mathrm{mg} \cdot \mathrm{L}^{-1}\right)$ & 0.26 & 0.19 & 0.68 & 1.9 \\
\hline \multirow[t]{2}{*}{ Temperature $\left({ }^{\circ} \mathrm{C}\right)$} & 16.8 & 19 & 24.8 & 26.5 \\
\hline & \multicolumn{4}{|c|}{ Consorted with pig manure Ituporanga } \\
\hline Dissolved oxygen $\left(\mathrm{mg} . \mathrm{L}^{-1}\right)$ & 7.95 & 2.34 & 6.12 & 2.75 \\
\hline Transparency & 15 & 22 & 10 & 10 \\
\hline $\mathrm{pH}$ & 7.07 & 7.01 & 7.22 & 6.85 \\
\hline Ammonia $\left(\mathrm{mg} . \mathrm{L}^{-1}\right)$ & 0.39 & 1.2 & 0.89 & 0.79 \\
\hline Temperature $\left({ }^{\circ} \mathrm{C}\right)$ & 15.8 & 23.4 & 23.7 & 22.4 \\
\hline
\end{tabular}


Table 3. Mean values and standard deviation of hematological parameters in Nile tilapia in each season and facilities from the state of Santa Catarina, southern Brazil.

\begin{tabular}{|c|c|c|c|c|}
\hline \multirow{2}{*}{ Parameters } & Autumn & Winter & Spring & Summer \\
\hline & \multicolumn{4}{|c|}{ Traditional fish farm - Joinville } \\
\hline Hematocrit $(\%)$ & $24.85 \pm 3.62^{\mathrm{bcB}}$ & $24.60 \pm 3.22^{\mathrm{cB}}$ & $28.00 \pm 4.55^{\mathrm{bA}}$ & $29.90 \pm 3.81^{\mathrm{aA}}$ \\
\hline Erythrocytes $\left(\times 10^{6} . \mu \mathrm{L}^{-1}\right)$ & $1.48 \pm 2.15^{\mathrm{aB}}$ & $1.09 \pm 0.51^{\mathrm{bB}}$ & $1.09 \pm 0.27^{\mathrm{bB}}$ & $1.57 \pm 0.37^{\mathrm{aA}}$ \\
\hline Thrombocytes $\left(\times 10^{3} \cdot \mu \mathrm{L}^{-1}\right)$ & $62.55 \pm 12.96^{\mathrm{aB}}$ & $26.77 \pm 15.49^{\mathrm{bB}}$ & $25.23 \pm 11.10^{\mathrm{bB}}$ & $10.99 \pm 5.23^{\mathrm{cA}}$ \\
\hline \multirow[t]{2}{*}{ Leukocytes $\left(\times 10^{3} \cdot \mu \mathrm{L}^{-1}\right)$} & $37.73 \pm 10.98^{\mathrm{aB}}$ & $33.96 \pm 18.27^{\mathrm{aB}}$ & $25.73 \pm 13.37^{\mathrm{abB}}$ & $45.74 \pm 19.87^{\mathrm{aA}}$ \\
\hline & \multicolumn{4}{|c|}{ Fee-fishing - Blumenau } \\
\hline Hematocrit $(\%)$ & $31.05 \pm 6.68^{\mathrm{aA}}$ & $28.85 \pm 6.86^{\mathrm{aA}}$ & $29.80 \pm 3.46^{\mathrm{aA}}$ & $32.58 \pm 0.65^{\mathrm{aA}}$ \\
\hline Erythrocytes $\left(\times 10^{6} . \mu \mathrm{L}^{-1}\right)$ & $2.55 \pm 0.92^{\mathrm{aA}}$ & $1.41 \pm 0.27^{\mathrm{bB}}$ & $1.49 \pm 0.39^{\mathrm{bA}}$ & $1.38 \pm 0.40^{\mathrm{bA}}$ \\
\hline Thrombocytes $\left(\times 10^{3} \cdot \mu \mathrm{L}^{-1}\right)$ & $82.87 \pm 36.17^{\mathrm{aA}}$ & $38.49 \pm 13.99^{\mathrm{bB}}$ & $36.44 \pm 11.51^{\mathrm{bA}}$ & $8.47 \pm 5.13^{\mathrm{cA}}$ \\
\hline \multirow[t]{2}{*}{ Leukocytes $\left(\times 10^{3} \cdot \mu \mathrm{L}^{-1}\right)$} & $68.51 \pm 22.37^{\mathrm{aA}}$ & $38.96 \pm 11.40^{\mathrm{bB}}$ & $32.70 \pm 16.04^{\mathrm{bB}}$ & $28.34 \pm 10.89^{\mathrm{bB}}$ \\
\hline & \multicolumn{4}{|c|}{ Consorted with pig manure - Ituporanga } \\
\hline Hematocrit $(\%)$ & $33.40 \pm 3.19^{\mathrm{aA}}$ & $27.83 \pm 6.00^{\mathrm{bAB}}$ & $28.18 \pm 3.85^{\mathrm{bA}}$ & $32.58 \pm 2.86^{\mathrm{aA}}$ \\
\hline Erythrocytes $\left(\times 10^{6} . \mu \mathrm{L}^{-1}\right)$ & $1.65 \pm 0.25^{\mathrm{bB}}$ & $2.19 \pm 0.79^{\mathrm{aA}}$ & $1.51 \pm 0.45^{\mathrm{bcA}}$ & $1.29 \pm 0.39^{\mathrm{cA}}$ \\
\hline Thrombocytes $\left(\times 10^{3} \cdot \mu \mathrm{L}^{-1}\right)$ & $75.48 \pm 16.37^{\mathrm{aAB}}$ & $59.10 \pm 20.81^{\mathrm{aA}}$ & $39.05 \pm 16.70^{\mathrm{bA}}$ & $10.03 \pm 5.71^{\mathrm{cA}}$ \\
\hline Leukocytes $\left(\times 10^{3} \cdot \mu \mathrm{L}^{-1}\right)$ & $51.21 \pm 13.46^{\mathrm{bB}}$ & $73.68 \pm 29.41^{\mathrm{aA}}$ & $50.10 \pm 19.38^{\mathrm{bA}}$ & $31.58 \pm 13.74^{\mathrm{cB}}$ \\
\hline
\end{tabular}

Capital letters indicate significant difference among facilities in each season and lowercase letters indicate the difference at the same facility $(\mathrm{p}<0.05)$.

Table 4. Mean values and standard deviation of hematological parameters in Nile tilapia in each season and facilities from the state of Santa Catarina, southern Brazil. Capital letters indicate significant difference among facilities in each season and lowercase letters indicate the difference at the same facility $(\mathrm{p}<0.05)$.

\begin{tabular}{|c|c|c|c|c|}
\hline \multirow{2}{*}{ Parameters } & Autumn & Winter & Spring & Summer \\
\hline & \multicolumn{4}{|c|}{ Traditional fish farm - Joinville } \\
\hline Monocytes $\left(\times 10^{3} \cdot \mu \mathrm{L}^{-1}\right)$ & $0.45 \pm 0.43^{\text {bcB }}$ & $1.06 \pm 0.91^{\mathrm{aB}}$ & $0.76 \pm 0.91^{\mathrm{abA}}$ & $0.19 \pm 0.11^{\mathrm{cB}}$ \\
\hline Lymphocytes $\left(\times 10^{3} . \mu \mathrm{L}^{-1}\right)$ & $35.14 \pm 9.67^{\mathrm{bcA}}$ & $31.89 \pm 18.18^{\mathrm{aB}}$ & $21.47 \pm 13.98^{\mathrm{bB}}$ & $1.80 \pm 0.77^{\mathrm{cA}}$ \\
\hline Neutrophils $\left(\times 10^{3} \cdot \mu \mathrm{L}^{-1}\right)$ & $2.14 \pm 1.82^{\mathrm{bB}}$ & $1.00 \pm 1.04^{\mathrm{bB}}$ & $16.80 \pm 151.87^{\mathrm{aA}}$ & $0.27 \pm 0.27^{\mathrm{bC}}$ \\
\hline \multirow[t]{2}{*}{ Basophils $\left(\times 10^{3} \cdot \mu \mathrm{L}^{-1}\right)$} & $0^{\mathrm{aA}}$ & $0.01 \pm 0.04^{\mathrm{aA}}$ & $0.02 \pm 0.07^{\mathrm{aA}}$ & $0.02 \pm 0.04^{\mathrm{aA}}$ \\
\hline & \multicolumn{4}{|c|}{ Fee-fishing - Blumenau } \\
\hline Monocytes $\left(\times 10^{3} . \mu \mathrm{L}^{-1}\right)$ & $5.055 \pm 0.94^{\mathrm{aA}}$ & $3.47 \pm 0.26^{\mathrm{aA}}$ & $1.29 \pm 0.86^{\mathrm{bA}}$ & $1.38 \pm 0.25^{\mathrm{bA}}$ \\
\hline Lymphocytes $\left(\times 10^{3} \cdot \mu \mathrm{L}^{-1}\right)$ & $47.73 \pm 19.10^{\mathrm{aA}}$ & $25.97 \pm 6.58^{\mathrm{bB}}$ & $25.57 \pm 11.17^{\mathrm{bB}}$ & $23.84 \pm 9.46^{\mathrm{bA}}$ \\
\hline Neutrophils $\left(\times 10^{3} \cdot \mu \mathrm{L}^{-1}\right)$ & $16.05 \pm 7.14^{\mathrm{aA}}$ & $9.87 \pm 5.84^{\mathrm{bA}}$ & $5.91 \pm 5.73^{\mathrm{bcB}}$ & $2.78 \pm 2.01^{\mathrm{cA}}$ \\
\hline \multirow[t]{2}{*}{ Basophils $\left(\times 10^{3} \cdot \mu \mathrm{L}^{-1}\right)$} & $0^{\mathrm{aA}}$ & $0^{\mathrm{aA}}$ & $0.02 \pm 0.06^{\mathrm{aA}}$ & $0.04 \pm 0.12^{\mathrm{aA}}$ \\
\hline & \multicolumn{4}{|c|}{ Consorted with pig manure - Ituporanga } \\
\hline Monocytes $\left(\times 10^{3} \cdot \mu \mathrm{L}^{-1}\right)$ & $1.52 \pm 1.39^{\mathrm{aB}}$ & $1.63 \pm 1.92^{\mathrm{aB}}$ & $0.70 \pm 0.70^{\mathrm{aA}}$ & $0.98 \pm 0.92^{\mathrm{aAB}}$ \\
\hline Lymphocytes $\left(\times 10^{3} \cdot \mu \mathrm{L}^{-1}\right)$ & $45.98 \pm 11.34^{\mathrm{aA}}$ & $67.68 \pm 24.55^{\mathrm{aA}}$ & $48.17 \pm 18.49^{\mathrm{bA}}$ & $29.26 \pm 13.23^{\mathrm{cA}}$ \\
\hline Neutrophils $\left(\times 10^{3} \cdot \mu \mathrm{L}^{-1}\right)$ & $125.62 \pm 77.44^{\mathrm{aA}}$ & $4.34 \pm 4.97^{\mathrm{bB}}$ & $1.23 \pm 1.02^{\mathrm{bB}}$ & $1.37 \pm 1.29^{\mathrm{bB}}$ \\
\hline Basophils $\left(\times 10^{3} \cdot \mu \mathrm{L}^{-1}\right)$ & $0^{\mathrm{aA}}$ & $0^{\mathrm{aA}}$ & $0^{\mathrm{aA}}$ & $0^{\mathrm{aA}}$ \\
\hline
\end{tabular}

for aquaculture (Simões et al., 2008; Tavares-Dias et al., 2008). The highest values of dissolved oxygen observed in a pond of Joinville facility may have been related to the daily water renewal that was responsible for the high water clarity at this site in comparison to other facilities. In Ituporanga, low levels of oxygen in winter and summer were likely due to water stratification since this system does not present continuous flow of water. According to
Souza Filho et al. (2002) this normally occurs in consorted swine system. Low water quality in ponds located in Blumenau and Ituporanga were likely related to the lack of control in the fish stocking density and in the deposition of swine manure, respectively. The $\mathrm{pH}$ was kept within a typical range of values, but the highest ammonia levels observed in ponds of the Ituporanga facility did not cause fish mortality as registered by Azevedo et al. (2006a). Even 
though the water temperature had not been keeping on the recommended range for tilapia, which is between 27 and $32{ }^{\circ} \mathrm{C}$ (Kubitza, 2000), no behaviour changes were observed.

However, fish maintained in different production systems may present hematological changes that are reflective of their health status or an imbalance in their physiology (Ghiraldelli et al., 2006a).

Certain hematological characteristics showed seasonality throughout this period. An increase in the percentage of hematocrit and in the RBC of fish from Joinville in the summertime was in agreement with the results observed in tench (Guijarro et al., 2003; De Pedro et al., 2005). The high number of erythrocytes must be related to the "respiratory compensation" mechanism. According to Guijarro et al. (2003), this compensation is necessary for fish to keep high oxygen availability to tissues. At low temperatures, a decrease in RBC in cyprinids (Phreatichthys andruzzii); (Frangioni et al., 1997) characterised the smallest erythropoiesis in winter (Hofer et al., 2000). In this study, an increase in the number of RBC in fish from Ituporanga in winter might be related to low dissolved oxygen levels in which fish were trying to supply a demand for tissue oxygen in those conditions. Contrary to what was here observed, constant values of RBC were verified by Hofer et al. (2000).

The leukocytosis observed in fish from the Blumenau facility in autumn did not differ from that observed by De Pedro et al. (2005), who verified an increased number of WBC only in spring. On the other hand, the results of this study regarding leukocytosis corroborated the results of Guijarro et al. (2003). Leukocytes are cells that are directly associated with specific and unspecific immunological responses (Iwama and Nakanishi, 1996). An increase in the number of WBC in fish from Blumenau in autumn could be related to the fish culture handling in this facility, characterised by a high influx of fish as a result of stress (Martins et al., 2004a). On the contrary, leucopenia, observed in fish from Ituporanga in summer, might be associated with water quality as suggested by Lea Master et al. (1990). Leukocyte levels in blood vary according to environmental quality (Lea Master et al., 1990), nutritional state (Barros et al., 2002), the presence of infectious agents (Martins et al., 2008) and parasitism (Martins et al. 2004b). In this study, changes in fish from Ituporanga could be explained by the high water temperature observed in this location in summer, which would allow the decomposition of organic matter and/or swine manure. This situation would mobilise leukocytes to other organs (Ghiraldelli et al., 2006b). Therefore, these results demonstrated that there is seasonality in blood parameters in Nile tilapia, primarily in the number of RBCs and WBCs throughout the year.

In autumn, fish from all regions showed an increased number of total thrombocytes, which are the cells responsible for blood coagulation (Clauss et al., 2008) and defense response (Tavares-Dias et al., 2007; Martins et al., 2008). In addition to macrophages, these cells have been found in the inflammatory exudates of fish (Matushima and Mariano,
1996; Martins et al., 2006). The low circulating number of thrombocytes in summer suggests the welfare of fish. It can also be commented on the higher number of thrombocytes in fish from Ituporanga in winter and spring, which received swine manure. The thrombocytopenic response as a result of releasing clotting factors in tissue damage conditions was suggested by Rahkonen and Pasternack (1998). However, in months of low water temperatures the immune response would be compromised and these cells could have an important role besides other cells.

Fish lymphocytes may be present in the inflammatory process and/or in cell-mediated humoral responses under different conditions (Iwama and Nakanishi, 1996). Lymphocytosis in fish from the Joinville and Blumenau facilities in autumn presented the same results when compared to Arctic char (Hofer et al., 2000), but differed from those found in tilapia by Ranzani-Paiva et al. (2005), who observed lymphocytosis in summer in southeast Brazil.

Lymphocytes are directly involved in the immunological responses of fish (Iwama and Nakanishi, 1996) and high numbers of lymphocytes, such as those observed in tilapia in autumn and winter, suggest stability in organisms. In tilapia, under normal conditions without the influence of stressors, lymphocytes are the most predominant cells (Ranzani-Paiva and Silva-Souza, 2004; Martins et al., 2004a; 2008). In contrast, lymphocytosis occurs in situations of chronic inflammatory infiltration (Iwama and Nakanishi, 1996). In tench, there was no observed change in the number of lymphocytes throughout the year (Guijarro et al., 2003; De Pedro et al., 2005).

Neutrophilia of fish from Blumenau and Ituporanga in autumn showed similar results to those of RanzaniPaiva et al. (2005) in tilapia and De Pedro et al. (2005) in tench. However, these results were not in agreement with the findings of Guijarro et al. (2003), who did not observe a relationship between granulocytes in different seasons of the year. In Southern Brazil, neutrophilia have been found in tilapia from fee fishing as a result of fish capture (Ghiraldelli et al., 2006a). The fish kept in facilities associated with swine production showed the highest number of circulating neutrophils due to the poor water quality and the high organic matter content, as suggested by Azevedo et al. (2006b). Neutrophils are cells responsible for phagocytosis and unspecific responses (Iwama and Nakanishi, 1996; Garcia-Navarro and Pachaly, 1994). For example, neutrophilia was observed under stressful conditions (Hofer et al., 2000; Martins et al., 2004a) and in response to parasitism (Silva-Souza et al., 2000; Tavares-Dias et al. 2008) and infection (Martins et al., 2004b). However, the number of granulocytes in the circulating blood could vary according to water quality (Lea Master et al., 1990; Barros et al., 2002). The high number of these cells in autumn, when water temperatures were maintained below those recommended for tilapia, might also be associated with the defense mechanisms of fish in this location (Ghiraldelli et al., 2006a).

In conclusion, these results indicate a seasonal influence of some hematological parameters in Nile tilapia. However, 
the handling conditions of each fish farm did interfere with the studied variables. Hematology is thus an important and practical tool for evaluating the physiological and health status of fish in aquaculture facilities.

Acknowledgements - The authors thank the "Coordenação de Aperfeiçoamento de Pessoal de Nível Superior" (CAPES) and the National Council of Scientific and Technologic Development (CNPq) for MSc grants to G.T. Jerônimo and G.M. Speck, for financial (CNPq 301072/2007-8, 501176/20055) support to M.L. Martins; SEAP (Secretaria Especial de Aquicultura e Pesca); AQUABRASIL project, EMBRAPA (Empresa Brasileira de Pesquisa Agropecuária, MPA, CNPq); Roberto Hoppe (Fish farm Fundação 25 de Julho, Joinville, SC, Brazil); Claudemir Luiz Schappo (Epagri, Ituporanga, SC, Brazil); Fee fishing Recanto da Divisa, Blumenau, SC, Brazil; Amilton Luiz for fish donation; Dr. Juan R. Esquivel (Fish farm Panamá, Paulo Lopes, SC, Brazil) and Dr. Ricardo M. Takemoto (NUPELIA, State University of Maringá, PR, Brazil) for the critical review of the manuscript.

\section{References}

AZEVEDO, TMP., MARTINS, ML., BOZZO, FR. and MORAES, FR., 2006a. Haematological and gill responses in parasitized tilapia from Valley of Tijucas River, SC, Brazil. Scientia Agricola, v. 63 , n. 2 , p. $115-120$.

AZEVEDO, TMP., MARTINS, ML., YAMASHITA, MM. and FRANCISCO, CJ., 2006b. Haematology of Oreochromis niloticus: comparison between fish maintained in a fish farm associated with pigs and in fee fishing in the Valley of Tijucas River, Santa Catarina, Brazil. Boletim do Instituto de Pesca, v. 32, n. 1, p. 41-49.

BARROS, MM., PEZZATO, LE., KLEEMANN, GK., HISANO, H. and ROSA, GJM., 2002. Níveis de vitamina C e ferro para tilapia do Nilo (Oreochromis niloticus). Revista Brasileira de Zootecnia, v. 3, n. 6, p. 2149-2156.

BENLI, ACK. and YAVUZCAN, HY., 2004. Blood parameters in Nile tilapia (Oreochromis niloticus L.) spontaneously infected with Edwardsiella tarda. Aquaculture Research, v. 35, n. 14, p. 1388-1390. http://dx.doi.org/10.1111/j.1365-2109.2004.01158.x

CLAUSS, TM., DOVE, ADM. and ARNOLD, JE., 2008. Hematologic Disorders of Fish. Veterinary Clinics Exotic Animal Practice, v. 11, p. 445-462.

DE PEDRO, N., GUIJARRO, AI., LÓPEZ-PATIÑO, MA, MARTÍNEZ-ÁLVAREZ, R. and DELGADO, MJ., 2005. Daily and seasonal variations in hematological and biochemical parameters in the tench, Tinca tinca Linnaeus, 1758. Aquaculture Research, v. 36 , n. 12 , p. 1185-1196. http://dx.doi.org/10.1111/j.13652109.2005.01338.x

FRANGIONI, G., BERTI, R. and BORGIOLO, G., 1997. Hepatic respiratory compensation and haematological changes in the cave cyprinid, Phreatichthys andruzzi. Journal of Comparative Physiology, v. 167, n. 7, p. 461-467.

GARCIA-NAVARRO, CEK. and PACHALY, JR., 1994. Manual de hematologia veterinária. São Paulo. 169 p.

GHIRALDELLI, L., MARTINS, ML., YAMASHITA, MM. and JERÔNIMO, GT., 2006a. Haematology of Oreochromis niloticus (Cichlidae) and Cyprinus carpio (Cyprinidae) maintained in different conditions of handling and feeding from the State of Santa Catarina, Brazil. Acta Scientiarum Biological Sciences, v. 28, n. 4 , p. $319-325$.
-, 2006b. Ectoparasites influence on the haematological parameters of Nile tilapia and carp cultured in the State of Santa Catarina, South Brazil. Journal of Fisheries and Aquatic Sciences, v. 1, n. 3, p. 270-276. http://dx.doi.org/10.3923/jfas.2006.270.276

GOLDENFARB, PB., BOWYER, FP., HALL, E. and BROSIOUS, E., 1971. Reproductibility in the hematology laboratory: the microhematocrit determination. American Journal of Clinical Pathology, v. 56, n. 1, p. 35-39. PMid:5556212.

GRASSHOFF, K., 1976. Methods of seawater analysis. New York: Weinheim Verlag Chemie.

GUIJARRO, AI., LOPEZ-PATIÑO, MA., PINILLOS, ML. ISORNA, E., DE PEDRO, N., ALONSO-GÓMEZ, AL., ALONSOBEDATE, M. and DELGADO, MJ., 2003. Seasonal changes in haematology and metabolic resources in the tench. Journal of Fish Biology, v. 62, n. 4, p. 803-815. http://dx.doi.org/10.1046/j.10958649.2003.00066.x

HOFER, R., STOLL, M., ROMANI, N., KOCH, F. and SORDYL, H., 2000. Seasonal changes in blood cells of Artic char (Salvelinus alpinus L.) from a high mountain lake. Aquatic Sciences, v. 62, n. 4, p. 308-319. http://dx.doi.org/10.1007/PL00001337

ISHIKAWA, NM., RANZANI-PAIVA, MJT. and LOMBARDI, JV., 2008. Total leukocyte counts methods in fish, Oreochromis niloticus. Archives of Veterinary Science, v. 13, n. 1, p. 54-63.

IWAMA, G. and NAKANISHI, T., 1996. The immune system. Califórnia: Academic Press. 380 p.

KUBITZA, F., 2000. Tilápia: tecnologia e planejamento na produção comercial. Jundiaí: Acqua Supre Com. Suprim. Aqüicultura Ltd. 289 p.

LEA MASTER, BR., BROCK JA., FUJIOKA, RS. and NAKAMURA, RM., 1990. Hematologic and blood chemistry values for Sarotherodon melanotheron and a red hybrid tilapia in freshwater and seawater. Comparative Biochemistry and Physiology, v. 97A, n. 4, p. 525-529.

MARTINS, ML., PILARSKY, F., ONAKA EM., NOMURA, DT, FENERICK JJ., RIBEIRO, K., MYIAZAKI, DMY., CASTRO, MP. and MALHEIROS, EB., 2004a. Haematology and acute inflammatory response of Oreochromis niloticus (Osteichthyes: Cichlidae) submitted to a single and consecutive stress of capture. Boletim do Instituto de Pesca, v. 30, n. 1, p. 71-80.

MARTINS, ML., TAVARES-DIAS, M., FUJIMOTO, RY., ONAKA, EM. and NOMURA, DT., 2004b. Haematological alterations of Leporinus macrocephalus (Osteichthyes: Anostomidae) naturally infected by Goezia leporini (Nematoda: Anisakidae) in fish pond. Arquivo Brasileiro de Medicina Veterinária e Zootecnia, v. 56, n. 5 , p. $640-646$

MARTINS, ML., MORAES, FR., FUJIMOTO, RY., ONAKA, EM., BOZZO, FR. and MORAES, JRE., 2006. Carrrageenin induced inflammation in Piaractus mesopotamicus (Osteichthyes: Characidae) cultivated in Brazil. Boletim do Instituto de Pesca, v. 32, n. 1, p.31-39.

MARTINS, ML., MOURIÑO, JL., AMARAL, GV., VIEIRA, FN., DOTTA, G., JATOBÁ, AMB., PEDROTTI, FS., JERÔNIMO, GT., BUGLIONE-NETO, CC. and PEREIRA JG., 2008. Haematological changes in Nile tilapia experimentally infected with Enterococcus sp. Brazilian Journal of Biology, v. 68, n. 3, p. 631-637. http:// dx.doi.org/10.1590/S1519-69842008000300025

MATUSHIMA, ER. and MARIANO, M., 1996. Kinetics of the inflammatory reaction induced by carrageenin in the swimbladder 
of Oreochromis niloticus (Nile tilapia). Brazilian Journal of Veterinary Research and Animal Science, v. 33, n. 1, p. 5-10.

RAHKONEN, R. and PASTERNACK, M., 1998. Effect of experimental Diphyllobotrium dentriticum infection on the blood leucocytes pattern of brown trout at two temperature levels. Boreal Environmental Research, v. 3, p. 381-386.

RANZANI-PAIVA, MJT. and GODINHO, HM., 1985. Estudos hematológicos em curimbatá. Prochilodus scrofa Steindachner, 1881 (Osteichthyes, Cypriniformes, Prochilodontidae). Série vermelha. Boletim do Instituto de Pesca, v. 12, n. 2, p. 25-35.

RANZANI-PAIVA, MJT. and SILVA-SOUZA, AT., 2004. Haematology of Brazilian Fish. In RANZANI-PAIVA, MJT., TAKEMOTO, RM. and LIZAMA, MAP. (Eds.). Sanidade de Organismos Aquaticos. Ed Varela, São Paulo, p. 89-120.

RANZANI-PAIVA, MJT., FELIZARDO, NN. and LUQUE, JL., 2005. Parasitological and hematological analysis of Nile tilapia Oreochromis niloticus Linnaeus, 1757 from Guarapiranga reservoir, São Paulo State, Brazil. Acta Scientiarum Biological Sciences, v. 27, n. 3, p. 231-237.

ROSENFELD, G., 1947. Pancromic stain for haematology and clinical cytology. A new combination of the components MayGrünwald and Giemsa in just one formula for rapid staining. Memórias do Instituto Butantan, v. 20, p. 329-334.

SILVA-SOUZA, AT., ALMEIDA, SC. and MACHADO, PM., 2000. Effect of the infestation by Lernaea cyprinacea Linnaeus, 1758 (Copepoda, Lernaeidae) on the leucocytes of Schizodon intermedius Garavello \& Britski, 1990 (Osteichthyes, Anostomidae). Revista Brasileira de Biologia = Brazilian Journal of Biology, v. 60, n. 2, p. 217-220.

SIMÕES, FS., MOREIRA, AB., BISINOTI, MC., GIMENEZ, SMN. and YABE, MJS., 2008. Water quality index as a simple indicator of aquaculture effects on aquatic bodies. Ecological indicators, v. 8, p. 476-484. http://dx.doi.org/10.1016/j.ecolind.2007.05.002

SOUZA FILHO, J., SCHAPPO, CL. and TAMASSIA, STJ., 2002. Custo de Produção de Peixes de Água Doce: Modelo Alto Vale do Itajaí. Florianópolis: Instituto Cepa. 40 p.

-, 2003. Estudo de competitividade da piscicultura no Vale do Itajaí. Florianópolis: Instituto Cepa/SC/Epagri/Acaq. 40 p.

TAVARES-DIAS, M. and MORAES, FR., 2003. Características hematológicas de Tilapia rendalli Boulenger, 1896 (Osteichthyes: Cichlidae) capturada em "pesque-pague" de Franca, São Paulo, Brasil. Bioscience Journal, v. 19, n. 1, p. 107-114. http://dx.doi. org/10.1111/j.1439-0426.2007.00850.x

TAVARES-DIAS, M., ONO, EA., PILARSKI, F. and MORAES, FR., 2007. Can thrombocytes participate in the removal of cellular debris in the blood circulation of teleost fish? A cytochemical study and ultrastructural analysis. Journal of Applied Ichthyology, v. 73 , p. $709-712$.

TAVARES-DIAS, M., MORAES, FR. and MARTINS, ML., 2008. Hematological assessment in four Brazilian teleost fish with parasitic infections, collected in feefishing from Franca, São Paulo, Brazil. Boletim do Instituto de Pesca, v. 34, n. 2, p. 189-196.

TAVARES-DIAS, M., SCHALCH, SHC., SILVA, ED., MORAES, FR. and MARTINS, ML., 2000. Características hematológicas de Oreochromis niloticus (Osteichthyes: Cichlidae) cultivadas intensivamente em "pesque-pague" do município de Franca, São Paulo, Brasil. Ars Veterinaria, v. 16, n. 2, p. 76-82.

ZANIBONI FILHO, E., 2004. Piscicultura das espécies exóticas de água doce In POLI, CR., POLI, ATB., ANDREATTA, ER. and BELTRAME, E. (Eds) Aqüicultura: experiências brasileiras. Florianópolis. p. 309-336.

ZAR, JH., 1999. Biostatistical Analysis. 4nd ed. New Jersey: Upper Saddle River. 662 p. 
